\title{
Sciendo
}

\section{A Monstrous Morality: Tzitzimime and their Relatives as Enforcers of Social Control}

\author{
KATHRYN M. HUDSON - JOHN S. HENDERSON* \\ Department of Anthropology and Department of Linguistics, \\ University at Buffalo, USA \\ khudson@buffalo.edu \\ *Department of Anthropology, \\ Cornell University, USA \\ jsh6@cornell.edu
}

\begin{abstract}
The tzitzimime - as reflected in central Mexican ethnohistorical sources and precolumbian imagery - represent a diverse array of mostly female divinities associated with fertility. Under Spanish influence, they were re-conceptualized as malevolent, mostly male agents of the Christian devil. Related beings attested elsewhere, especially in the ethnography of eastern Mesoamerica, are distinctly monstrous. They are particularly salient in "wild" contexts, outside the realm of culture, and serve as enforcers of social norms. This paper traces the development of these creatures from their quasi-monstrous tzitzimime forbears and considers how they have been - and continue to be - conceptualized in relation to sociopolitical differences in their cultural contexts.
\end{abstract}

KEY WORDS: deities, ethnohistory, iconography, Mesoamerica, monsters

\section{Introduction}

Tzitzimime (singular tzitzimitl) is most familiar as a label for dangerous and monstrous Aztec deities (see Figure 1) who will descend from the celestial realm to devour humanity at the next cyclical destruction of the universe (Boone 1999; Klein 2000). In fact, this view reflects 
the perspective of the Colonial period Spanish churchmen who presided over the demonization of the tzitzimime as much as it does pre-Columbian Aztec belief. Today, similarly monstrous and dangerous supernatural beings, often called sisimite, are widely believed to inhabit areas remote from human habitation, especially in the eastern regions of Mesoamerica (Costenla 1995; Dodds 2008, 92-97; Martínez and Mikulska 2016). Here we consider the nature of these beings and the beliefs and practices associated with them to assess the degree to which they can be understood in similar ways.

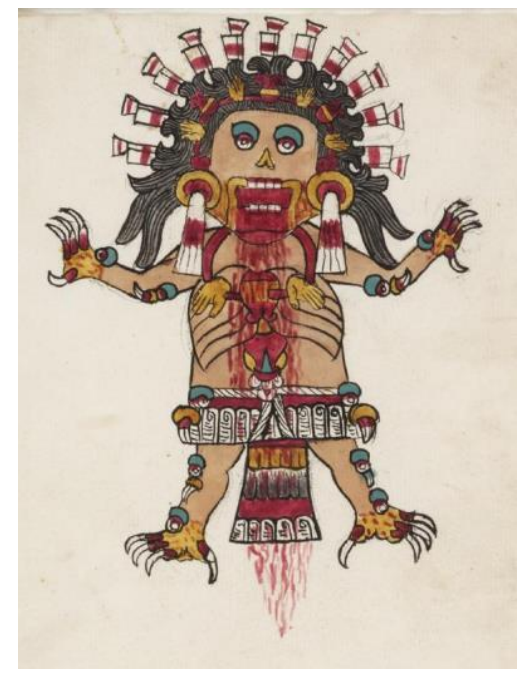

Figure 1: Tzitzimitl, Codex Tudela 46r (http://ceres.mcu.es/pages/Viewer?accion=41\&Museo=\&AMuseo=MAM\&Ninv=70400\&txt_id_imag en $=78 \& t x t$ rotar=0\&txt_contraste $=0 \& t x t \_z o o m=10 \&$ cabecera $\left.=N \& v i e w N a m e=v i s o r Z o o m\right)$.

During pre-Columbian times, tzitzimime were not monstrous in conventional ways. Like other supernatural beings, they could be frightening and dangerous and sometimes inflicted harm, though they were not thought to be fundamentally wicked or cruel. They were also not of unusual size, malformed, or particularly ugly. Anatomically, most or all tzitzimime were not identical to ordinary human beings, but neither were they unnatural in the sense of being composite, hybrid beings that combined anatomical features of different species in ways analogous to creatures from Bronze Age Mesopotamia and Egypt (Wengrow 2014). All of that changed following the Spanish invasion. Under the influence of Christian views of the world and the supernatural, the malevolent qualities and monstrous physical features of 
tzitzimime intensified as their benign aspects faded or were transferred to Christian supernaturals.

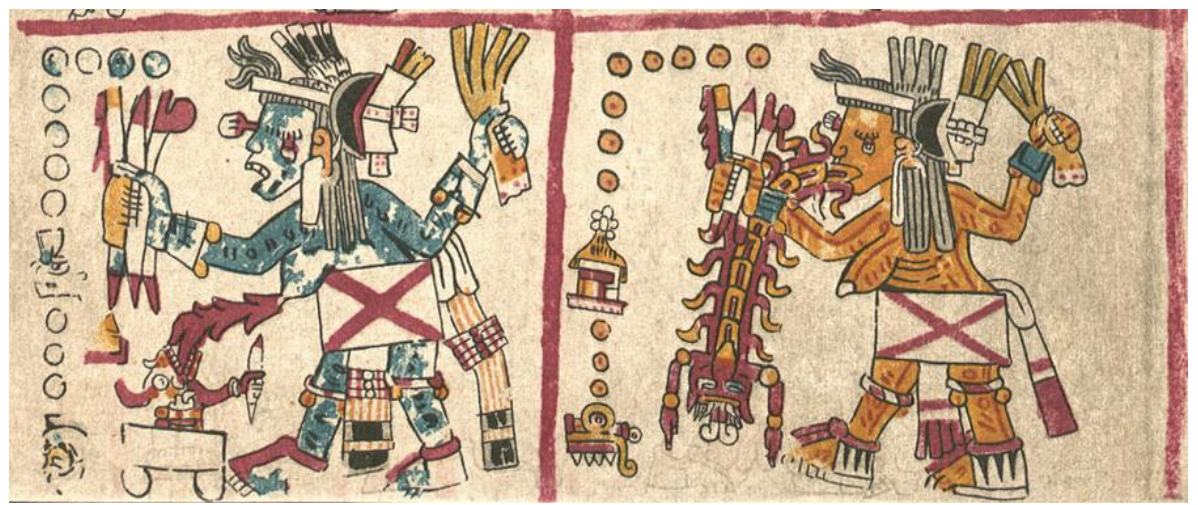

Figure 2: Tzitzimime who died during childbirth (Cihuateteo), Codex Vaticanus B 78 (Seler, Eduard, ed., 1902, Codex Vaticanus Nr. 3773 (Codex Vaticanus B): Eine altmexikanische Bilderschrift der Vatikanischen Bibliothek. Berlin: Druck von Gebr. Unger).

\section{Tzitzimime in pre-Columbian Aztec Belief}

According to central Mexican sources, - mostly early Colonial prose and pictorial documents, but also pre-Columbian imagery - tzitzimime include a diverse array of primarily female supernaturals. Some have negative associations such as disease and affliction, times of danger, and destruction; others have markedly positive connections with pregnancy, midwives, and healing. The most famous tzitzimime were women who died during childbirth (see Figure 2) and ascended to the sky, where they escorted the sun in his descent from noon to sunset. When the continuance of the sun's celestial progression was uncertain and the end of the universe might be imminent - as occurred on the occasion of a solar eclipse or the relighting of all fires at the end of each 52-year calendar cycle - tzitzimime could be expected to descend and bring death and destruction with them. The roles and associations of preColumbian tzitzimime are thus both malevolent and benign.

The number of names and epithets associated with tzitzimime (Table 1) is bewildering but two perspectives can help cut through this confusing nomenclature. The first is that tzitzimitl is not the name of a particular supernatural but instead designates a category to which a supernatural being may belong or a status that a supernatural can take on. The second relates to the ontology of the supernatural in Mesoamerica. Mesoamerican supernatural beings are 
Kathryn M. HUDSON - John S. HENDERSON

A Monstrous Morality: Tzitzimime and their Relatives as Enforcers of Social Control

not discrete, personified deities such as those that populate ancient Mediterranean pantheons. Rather, they are more like sets of supernatural forces and qualities that are context-specific and overlap with one another. Bundles that recur frequently were named, referred to, and depicted in ways that make them seem like stable, discrete personalities.

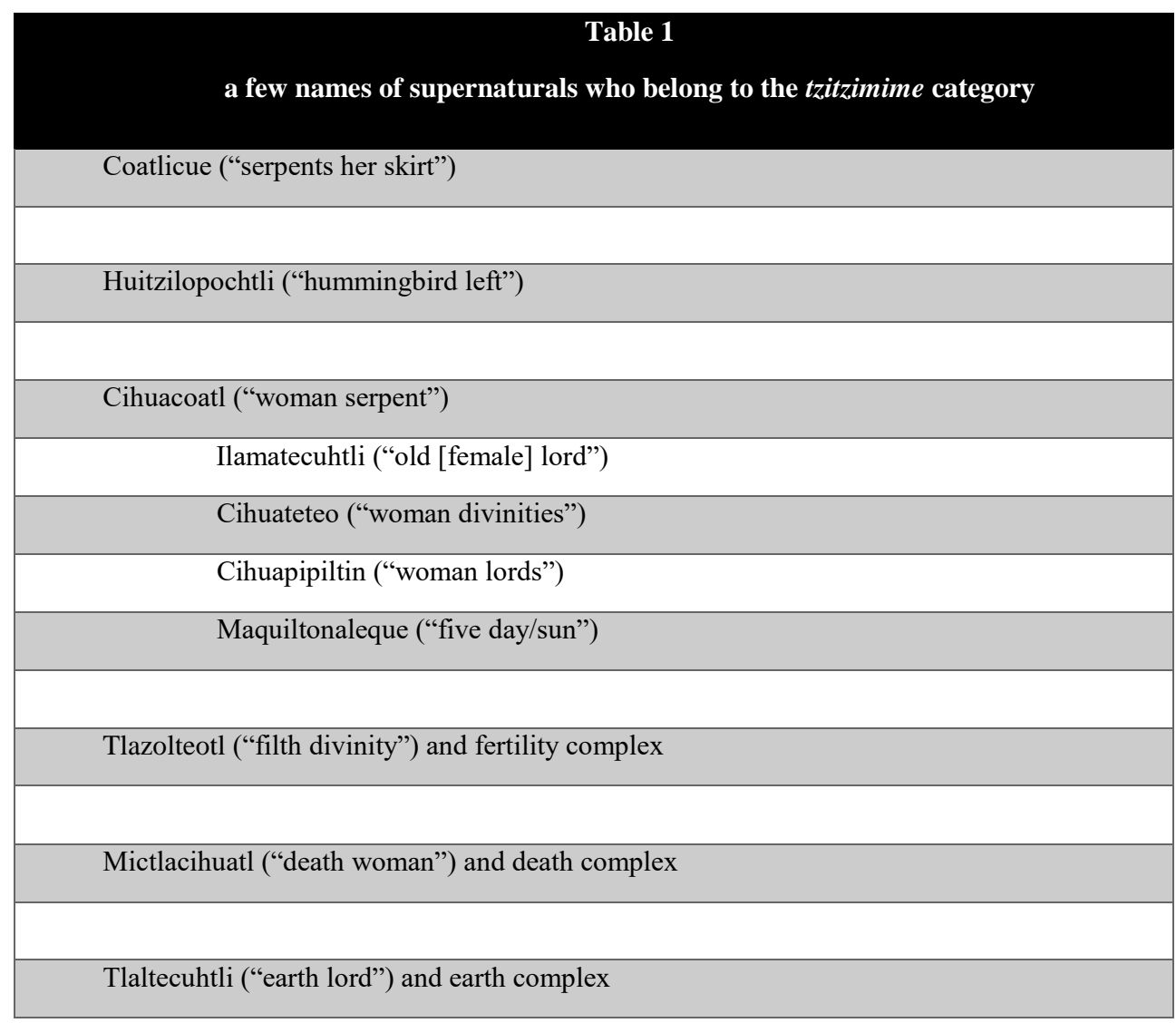

In the conventional view, page 36 of the Codex Borbonicus (see Figure 3) depicts one aspect of the deity Cihuacoatl - the one called Ilamatecuhtli - in its manifestation as a tzitzimitl. These terms are commonly understood as describing members of overlapping complexes of deities and their avatars - including Tlazolteotl, Mictlacihuatl, the Cihuateteo, and the Cihuapipiltin - that are associated with fertility, (transgressive) female sexuality, and death (Nicholson 1971, 420-422, 428; Hunt 1977, 100-102; see Table 1). However, it is more sensible to think of the image as a set of iconographic elements that refer to particular DOI: 10.2478/eas-2021-0020 @ University of SS. Cyril and Methodius in Trnava. All rights reserved. 
Kathryn M. HUDSON - John S. HENDERSON

A Monstrous Morality: Tzitzimime and their Relatives as Enforcers of Social Control

supernatural qualities that participate in multiple overlapping clusters. We focus here on three of the tzitzimime constellations: Coatlicue, Cihuacoatl, and Huitzilopochtli.

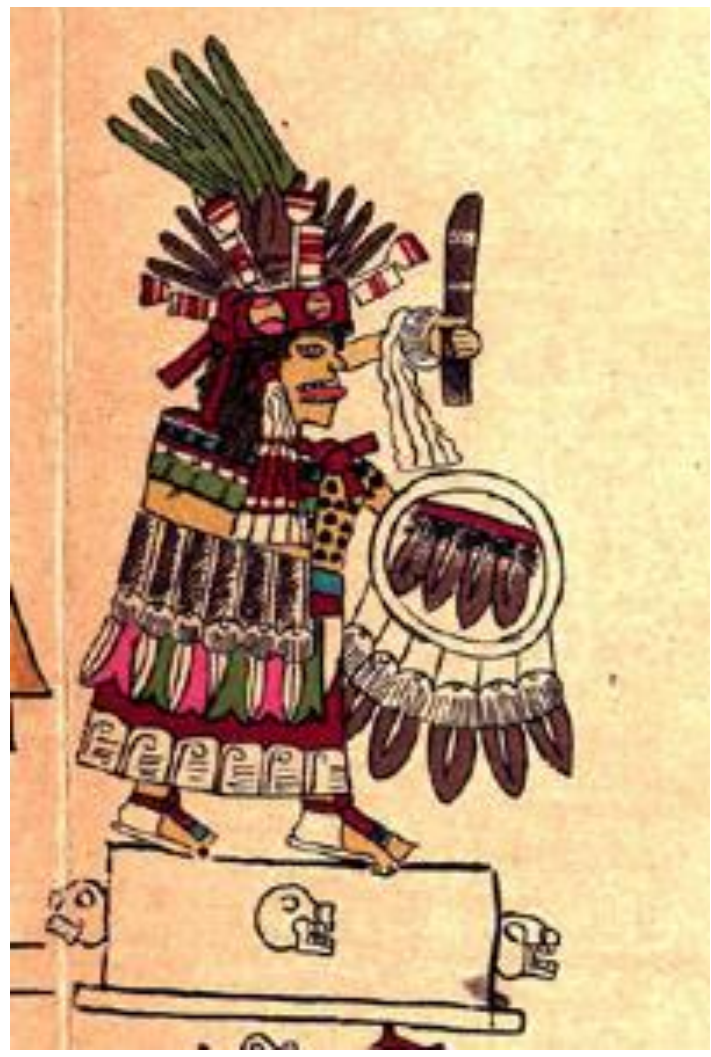

Figure 3: Cihuacoatl as Ilametecuhtli, Borbonicus 36 (Hamy, E.-T., ed., 1899, Codex Borbonicus: Manuscrit mexicain du Palais Bourbon. Paris: Ernest Leroux).

Coatlicue (Serpents her Skirt) is best known for her mythic role as the divine mother of Huitzilopochtli (see Figure 4), who was the sun and also the embodiment of the identity of the Mexica, the dominant ethnic group in the Aztec empire. A colossal image of her (see Figure 5) that stands more than 2.5 meters tall was found in 1790 near the Great Temple of the Aztec capital city of Tenochtitlan. It has usually been interpreted as a straightforward, stand-alone portrait of Coatlicue because of the intertwined snakes that form the skirt and visually echo her name. As Elizabeth Boone (1999) has pointed out, however, a second 
sculpture found nearby is virtually identical except that the skirt consists of human hearts; additional fragments represent at least one more member of a set of comparable sculptures (see also Klein 2008). Colonial histories report that statues of tzitzimime, in their role as sustainers of the sky, were placed around representations of Huitzilopochtli atop the Great Temple pyramid. Coatlicue - and related bundles of features usually conceptualized as her "sisters" - would certainly qualify as sustainers of the sun, since they sacrificed themselves to set the sun in motion at the beginning of the current creation.

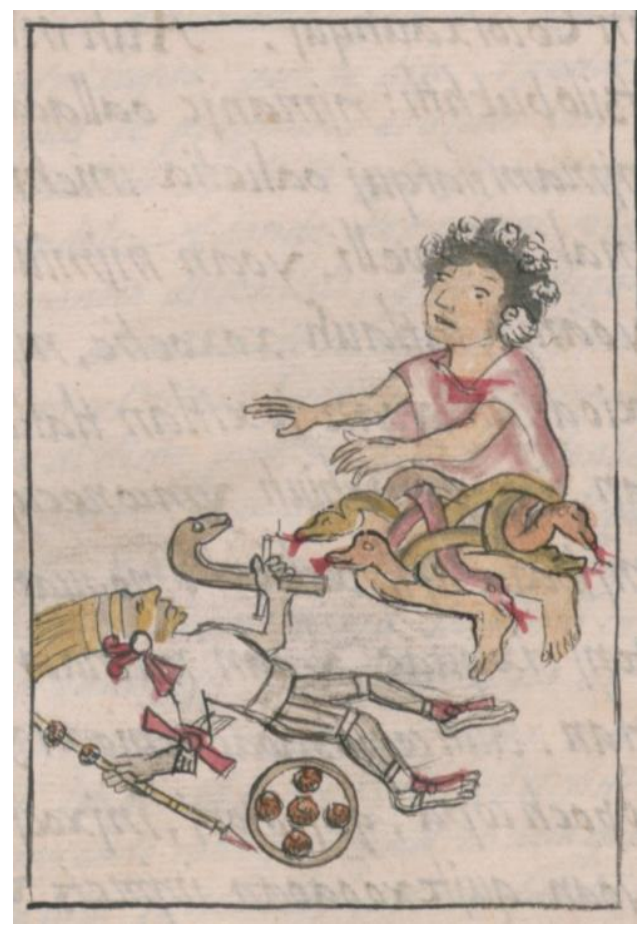

Figure 4: Coatlicue and newborn Huitzilopochtli, Florentine Codex, Book 3, Chapter 1, Folio 3v (https://www.wdl.org/en/item/10614/view/1/7/).

The colossal Coatlicue (see Figure 5) is the only well-preserved member of the sculptural set. It has features - most notably claws for hands and feet, a necklace made of human hands and hearts, fanged faces at the joints, and distinctive wrist and leg bands - that clearly mark it as a tzitzimitl. The snakes that emerge from the neck to form the head, and from the wrists to form the hands, represent streams of blood that refer to the self-sacrifice that animated the 
sun. The calendar date carved on Coatlicue's back connects the image to the end of an earlier creation in which tzitzimime descended from the skies and devoured humanity. The visual emphasis on skirts formed by snakes and hearts echoes an emphasis in Colonial documents on the garments of the tzitzimime, especially their skirts. Cecelia Klein (2000) argues persuasively that these garments embodied the tzitzimime and their powers; they had magical, protective capacities and were wrapped around images and bundles of sacred objects. The skirts, along with the tzitzimime themselves, were also embodied in altar-like architectural features.

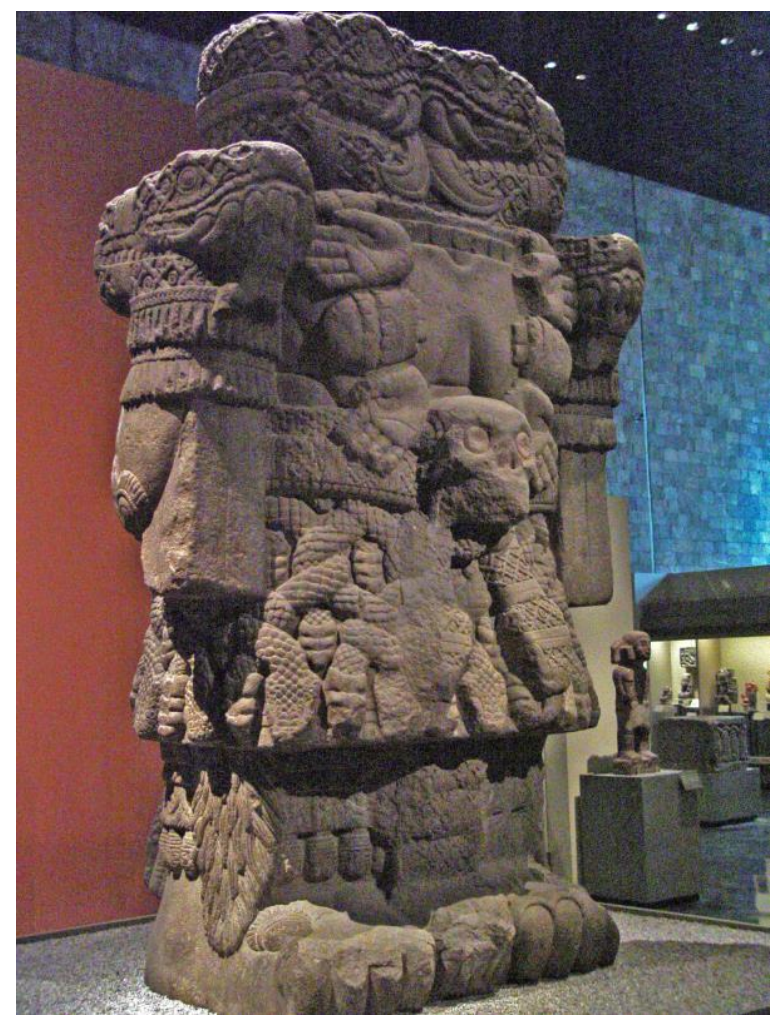

Figure 5: Coatlicue, Museo Nacional de Antropología, Mexico.

The sculptural program of the Great Temple shrine, with monumental images of tzitzimime surrounding the statue of Huitzilopochtli, is usually interpreted as a materialization of the myth of Huitzilopochtli's birth (Sahagún 1978, Book 3, 1-5; Matos 1987, 198-205; Matos 
1988, 135-145; Klein 2008, 229-231). In the story, Coatlicue - who was magically pregnant with Huitzilopochtli - retreated to the top of the hill Coatepec (represented by the temple pyramid). There the god was born, fully mature and armed, and defeated his sister Coyolxauhqui and their 400 (numberless) brothers who had come to kill her. Huitzilopochtli decapitated Coyolxauhqui and then threw her dismembered body down the slopes of Coatepec; a monumental relief image of Coyolxauhqui was set at the base of the stair of at least three of the successive enlargements of the Great Temple. The most obvious message of this narrative was the triumph of Huitzilopochtli, the embodiment of the identity and sovereignty of the Mexica and of their destiny to preside over the Aztec empire. The tableau can also be easily interpreted in terms of celestial metaphor - the sun daily puts to flight the moon (Coyolxauhqui) and the stars (the 400 brothers) - and is perfectly congruent with the tzitzimime identity of the principals and the complementarity of their behavior. Coatlicue and her sisters sacrificed themselves to set the sun in motion and then accompanied the sun in its daily descent from the zenith. Coyolxauhqui, the daughter of Coatlicue, was a sustainer of the sun in her tzitzimitl capacity but served as his adversary on other occasions, such as during solar eclipses when she and other nearby stars threatened to devour him. These interpretations are not mutually exclusive and it is likely that all were held simultaneously.

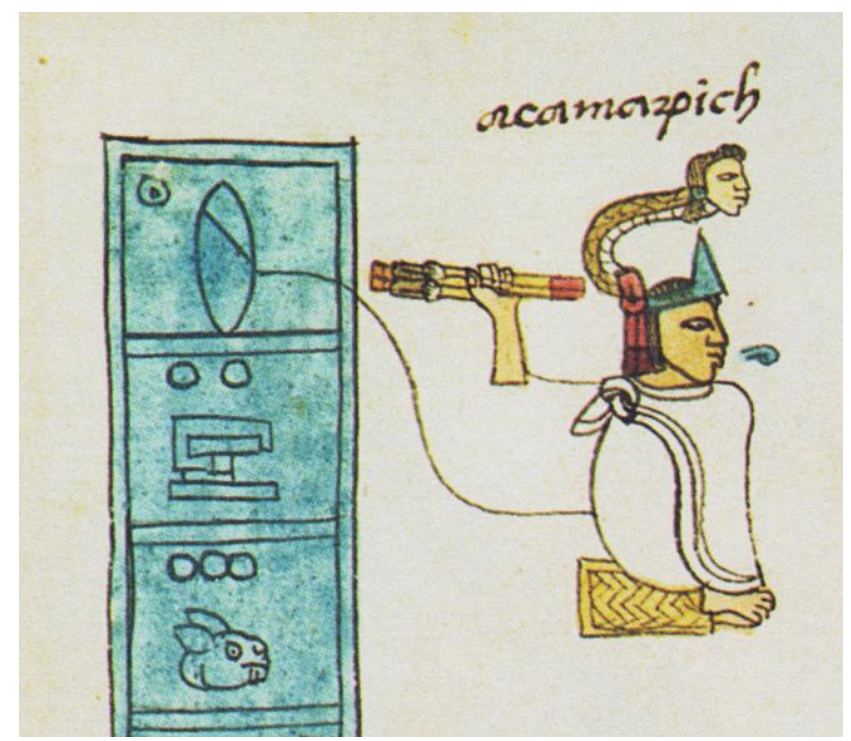

Figure 6: Acamapichtli as tlatoani (indicated by the blue scroll referring to the speaker title) and cihuacoatl ("woman serpent" marked by the snake body with a woman's head), Codex Mendoza, Folio $2 r$ (https://codicemendoza.inah.gob.mx/index.php?lang=spanish). 
Kathryn M. HUDSON - John S. HENDERSON

A Monstrous Morality: Tzitzimime and their Relatives as Enforcers of Social Control

The materialization of these relationships in the heart of the sacred precinct at the center of the empire would have reinforced the same complementarity that operated in the political domain and structured the relationship between the two most powerful political offices in the Aztec state: the tlatoani and the cihuacoatl. The tlatoani, or Speaker (see Figure 6), was the highest ranking and most powerful official of the Aztec state (Berdan 2014, 141-155). The cihuacoatl, or Woman Serpent, was almost as powerful (Klein 1988; Johansson 1998; Schroeder 2016); he served as prime minister for domestic affairs, finance, and administration; as chief judge; and as head of the council of lords that selected and advised the tlatoani. When the tlatoani was away on military campaigns, the cihuacoatl moved into the palace as acting ruler. Durán (1994, 231-232) describes Tlacaelel - the most famous incumbent of the cihuacoatl office - as the architect of the "flowery war," combat conducted by appointment to ensure that sufficient captured warriors were available to be sacrificed to nourish Huitzilopochtli.

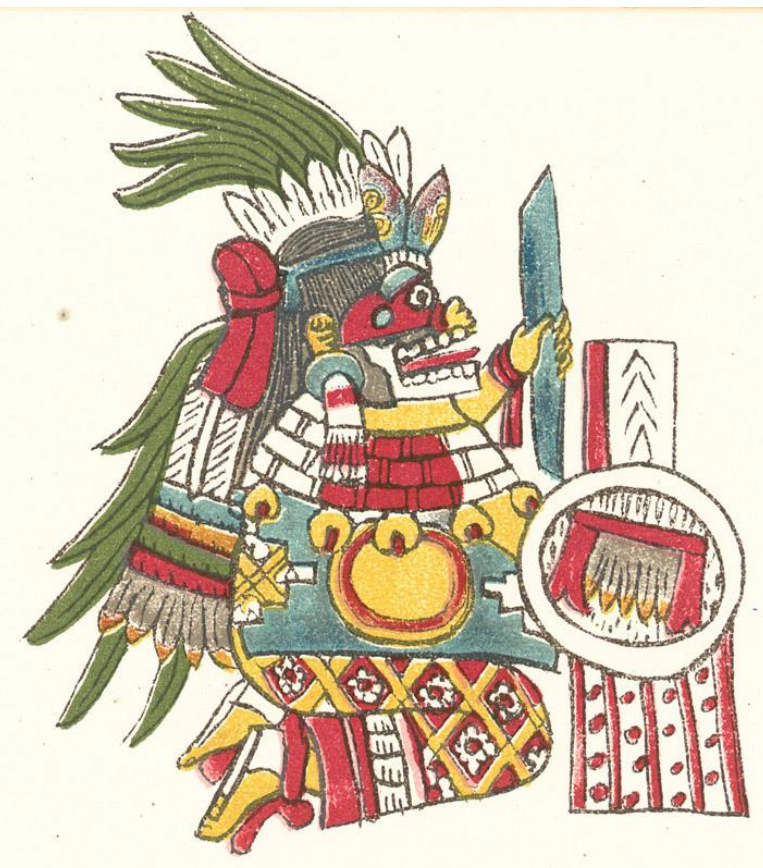

Figure 7: Cihuacoatl, Codex Magliabecchiano, Folio 45r (1904, Codex Magliabecchiano XIII. 3: Manuscrit mexicain post-Colombien de la Bibliothèque nationale de Florence. Rome: Stabilimento Danesi). 
The tlatoani was identified with Huitzilopochtli, the sun, who embodied the sovereignty of the state as well as Mexica identity. The office of cihuacoatl was named for a tzitzimitl (see Figure 7) associated with fertility, inversions of female sexuality, death, stars, and (indirectly via the fertility complex) the moon. Its political functions were complementary to those of the tlatoani, since the stellar and lunar connections of the deity complemented Huitzilopochtli's solar identity. The efficacy of the cihuacoatl in establishing a convenient source of the sacrificial victims needed to nourish Huitzilopochtli is also directly analogous to the sun-sustaining activities of Coatlicue and her tzitzimime relatives.

Tzitzimime were thus part of a "political cosmology" - a state-sanctioned view of the universe and of the roles of supernatural beings in it. Sometimes benign and sometimes malignant, tzitzimime embodied a balancing of dangerous forces within this official cosmology. Some of the harm they inflicted can be understood in relation to social control, as retribution for societal failure properly to nourish the sun. Some of their benefits include the supporting of the sun and, by extension, the perpetuation of Aztec people and society.

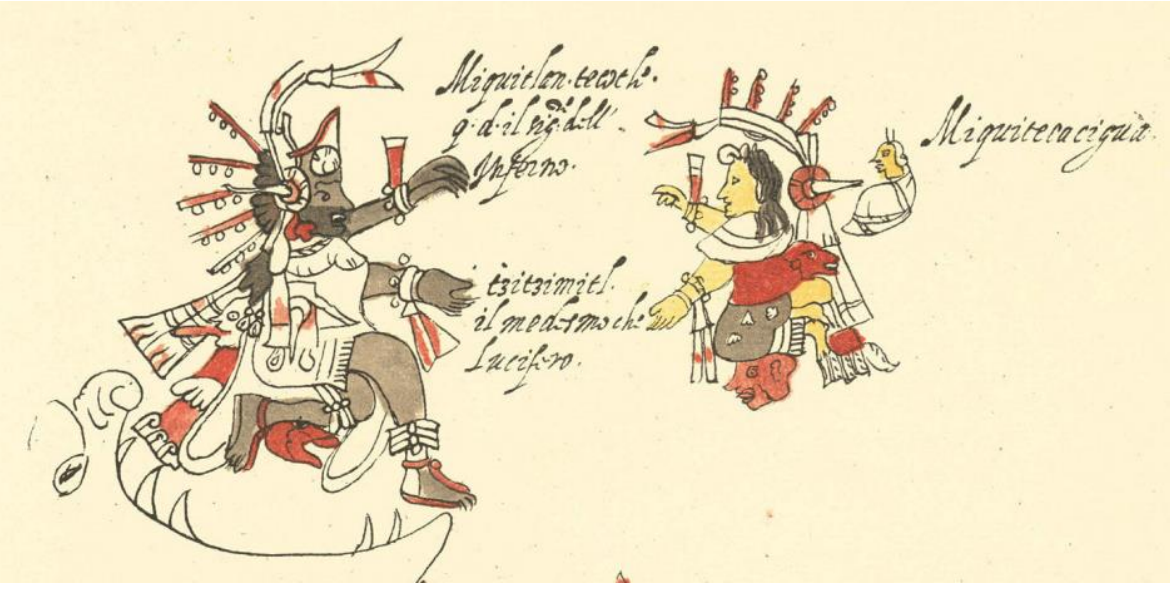

Figure 8: Tzitzimimitl as Lucifer, Codex Vaticanus A, Folio 2v (1900, II Manoscritto Messicano Vaticano 3738, detto il Codice Rios, Rome: Stabilimento Danesi).

\section{Colonial Transformations of Tzitzimime}

Tzitzimime were reconceptualized during the Colonial period (Klein 2000). Their political symbolism evaporated first as the contexts of political sovereignty where they were salient were steadily eliminated. They were also conflated with Christian supernaturals (see Figure DOI: 10.2478/eas-2021-0020 C University of SS. Cyril and Methodius in Trnava. All rights reserved. 
Kathryn M. HUDSON - John S. HENDERSON

A Monstrous Morality: Tzitzimime and their Relatives as Enforcers of Social Control

8); as a result of this process, tzitzimime became mostly male agents of the Christian devil and their malevolence and monstrousness were intensified. At least some of their benign qualities and actions were lost; others were transferred to various saints or to the Virgin Mary. An example can be found in Virgin of the Rosary in the highlands of Chiapas (Hunt 1977, 106).

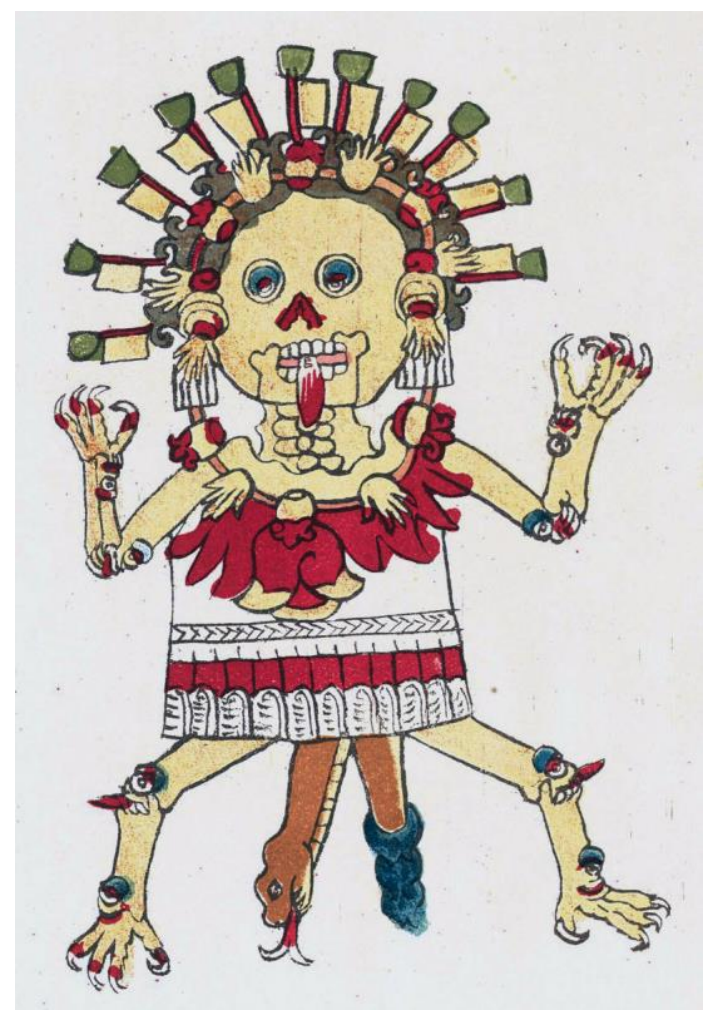

Figure 9: Tzitzimitl, Codex Magliabecchiano, Folio 76r (1904, Codex Magliabecchiano XIII. 3: Manuscrit mexicain post-Colombien de la Bibliothèque nationale de Florence. Rome: Stabilimento Danesi).

In contemplating the new fire ritual that occurred at the end of each 52-year cycle, Bernardino de Sahagún (1953, Book 7, 27) - the Franciscan compiler of a mid-sixteenth century encyclopedic account of all things Aztec - emphasized anxiety that was driven by the possibility that the procedure might fail: 
And when it came to pass that night fell, all were frightened and filled with dread. Thus it was said: it was claimed that if fire could not be drawn, then [the sun] would be destroyed forever; all would be ended; there would evermore be night. Nevermore would the sun come forth. Night would prevail forever, and the demons of darkness would descend, to eat men.

Reactions to a solar eclipse that took place during the reign of Ahuitzotl at the end of the fifteenth century are described in much the same way:

And it came to pass in his time that the sun was eclipsed, at midday. For about five hours the darkness was overspread; the stars appeared. All were much terrified. It was said: 'The demons of darkness will descend; they will eat people.' (Sahagún 1954, Book 8, 2).

Sahagún's extensive presentation of the voices of Nahua survivors of the Spanish invasion alongside his own synthesis makes the Florentine Codex more likely to reflect local belief than most Colonial period documents, but it is certainly not free of Spanish influence. Though tzitzimime still retained benign roles and associations - Alvarado Tezozomoc $(1975,451)$ reported late in the sixteenth century that tzitzimime held up the sky and brought the rains the process of demonization under the tutelage of Spanish churchmen is already obvious in Sahagún's emphasis on the malevolent and especially in his substitution of "demons of darkness" for tzitzimime.

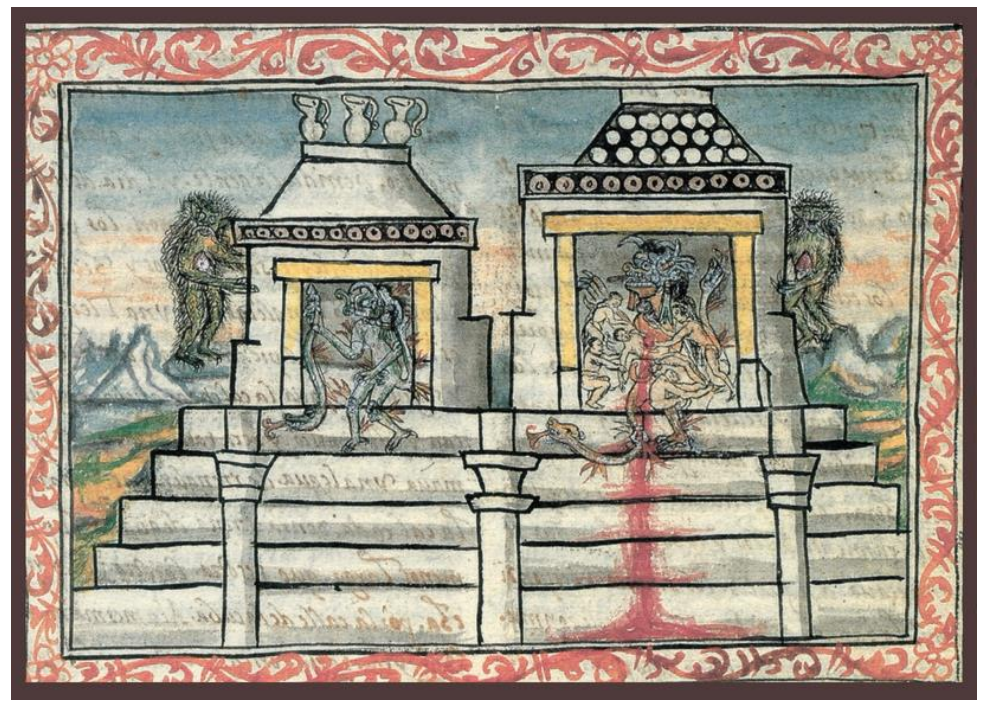

Figure 10: Main Temple, Tenochtitlan, Diego Durán, Historia de las Indias de Nueva España e islas de la tierra firme, Folio 131r (http://bdh-rd.bne.es/viewer.vm?id=0000169486\&page=1). 
Compared with pre-Columbian imagery, Colonial depictions of tzitzimime are striking for their threatening and monstrous countenances (see Figure 9). They appear with fleshless skulls and jaws and have open mouths with teeth bared. Claws are depicted in place of hands and feet, and they have tangled hair that conveys wildness. Often they are adorned with necklaces of human hands and hearts.

Durán's image of the Great Temple (see Figure 10) seems to reflect a further transformation. Two unclothed hairy figures with clawed hands and feet are shown flanking the shrines. The artist undoubtedly drew on European imagery of diabolical creatures, but these are surely the statues called tzitzimime that Durán's text (cit) says were set around Huitzilopochtli. Their position suggests the sustaining role that the text attributes to them. Their hairiness, lack of clothing, and apparent association with mountains seem to indicate wildness and an alienation from culture - features that are strongly reminiscent of the qualities of analogous ethnographic monsters.

The sumptuous feasts hosted by the lords of Tlaxcala, a culturally Aztec but politically independent state, point to another key feature of Colonial instantiations of tzitzimime that is shared with their ethnographic counterparts: social control. These feasts involved lavish gifts and extravagant servings of food and intoxicating drink that produced drunkenness and conflict along factional lines. John Pohl (1998) argues convincingly that the feasts were designed not only to create the obligations and indebtedness that structured a political system dependent on elite reciprocity but also to acknowledge and balance countervailing forces that threatened to rupture the system. Interacting with tzitzimime, and with the painted altars that embodied them, was central to the process of bolstering harmony by counterbalancing the dangerous forces. Tzitzimime were specially poised to maintain accord in the face of drunkenness, since among the 1600 offspring of the tzitzimitl genetrix were the supernatural patrons of pulque, the fermented drink served at these events.

The emphasis on wild hair in Colonial tzitzimitl imagery may signal another similarity with ethnographic monsters - the maintenance of social mores, especially in relation to sexual behavior and gender roles. Colonial period accounts emphasize the unkempt character of women who transgressed sexual norms (Arvey 1988, 182-184; Sigal 2011, 27). This is especially true of prostitutes (see Figure 11), who are often depicted with markedly wild hair. These representations are in sharp contrast with the neatly coiffed images of most women and, by extension, with the respectability associated with them. 


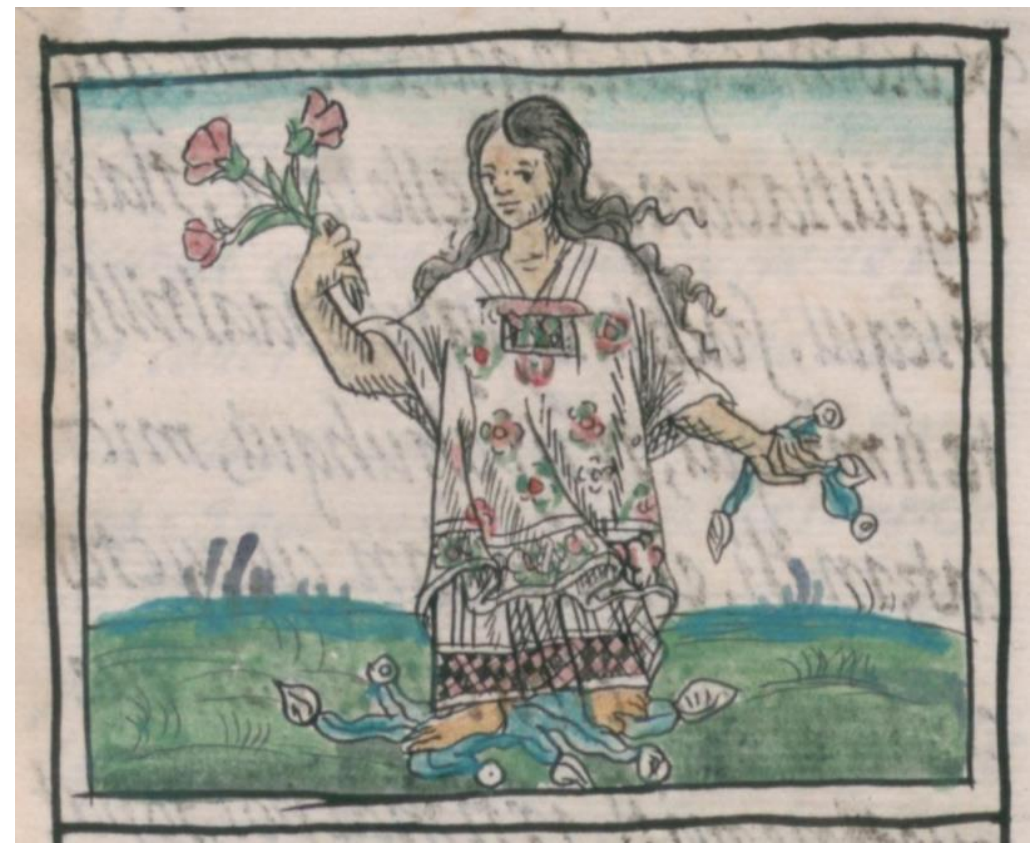

Figure 11: Prostitute, Florentine Codex, Book 10, Chapter 15, Folio 39v (https://www.wdl.org/en/item/10621/view/1/82/).

\section{Sisimite in Mesoamerican Ethnography}

Monstrous beings are very well attested in Mesoamerican ethnography, particularly in the belief systems of Maya and neighboring societies in eastern Mesoamerica (Hartman 1907, 144-146; Conzemius 1932, 168; Wisdom 1940, 406; Correa 1955, 68-69; Espino 1955, 5354; Aplicano Mendieta 1967; Blaffer 1972; Laughlin 1977, 71-73, 355-356, 391-392; Chapman 1982, 195-200; Chapman 1985, 215-237; Carías et al. 1988, 137-138; Costenla 1995; Escobar 2000, 22; Dixon 2008; Dodds 2008, 92-97; Quesada 2014; Martínez and Mikulska 2016). Like their pre-Columbian counterparts, ethnographic monsters are known by a staggering array of names. There is significant variability in their forms and behavior but also considerable overlap. In these contexts, the supernatural is once again conceptualized in terms of multiple overlapping clusters of forces and qualities rather than discrete, personified beings. 
Some ethnographic monsters are called by names that are derived from or otherwise relate to Nahuatl tzitzimitl: sisimite, sesimite, sisimique, chichimite, chichinite, and cihuatlpipil (e.g., Hartman 1907, 144-146; Conzemius 1932, 168; Olivera 1969; Chapman 1982, 195-200; Chapman 1985, 215-237; Carías et al. 1988, 137-138; Costenla 1995; Escobar 2000, 22; Quesada 2014). Sometimes these names are taken from local Spanish dialects and used as alternatives to traditional indigenous names for the same supernaturals. Other terms, mostly indigenous in origin, are much more localized: siguanaba is used in Pipil-Chortí (Espino 1955, 51-54; Wisdom 1940, 406-407), hitacay occurs in Tol (Aplicano Mendieta 1967, 17 18), and h7ik'al, Xpak'inte7 can be found in Tzotzil (Blaffer 1972; Hunt 1977, 105-106). There is disagreement, even among locals, about whether these labels refer to distinct beings. In one community in northern Nicaragua, they are variably described as ghosts - generically defined - and as specific supernatural entities with distinct personalities and motivation ${ }^{1}$. Despite this variability, shared physical features, characters, and behaviors clearly indicate that they can be treated as a single category which, for convenience, we call sisimite.

Sisimite are usually male but are also occasionally female. Although they are distinctly humanoid in form, sisimite have one or more unusual anatomical features and/or proportions. They are typically gigantic or unusually small in stature. Some of them have enormous penises, and many have reversed feet with formidable claws (Conzemius 1932, 168; Wisdom 1940, 406, Carías et al. 1988, 137; Costenla 1995). Some sisimite have wings or wing-like appendages attached to their feet or legs that enable them to fly; others are said to have tails (Olivera 1969).

Sisimite may embody inversions of normal sexuality. Among the Cuicatec in northeastern Oaxaca (Hunt 1977, 102-104), they appear to be female; however, that appearance is a ruse that allows them to entrap men inclined to transgress behavioral norms. A mouth-like hole in the back of the neck replaces the vagina so that the genitals are situated in upper back part of body instead of lower front. This front-back reversal suggests anal intercourse, as do reversed feet and identification of the vagina-equivalent in the neck as a mouth (since the anus is conceptualized as the mouth of the buttocks). Men who are tricked into having intercourse become pregnant and give birth to infants that resemble feces - the product of the anus. A man who recognizes the deception may put a (penis-like) lighted cigarette in the false vagina, producing pain rather than pleasure. The creature is then transformed into a snake that slithers

$1 \quad$ Based on the authors' fieldwork; the community is not identified here because many of its residents do not wish their beliefs to be made known to outsiders. 
away into the wild; its resemblance to a phallus is the definitive demonstration that the creature was not really female.

Sisimite are often covered with long, unkempt hair that takes the place of clothing; it is magically protective and is sometimes even impervious to bullets (Thompson 1930, 67; Laughlin 1977, 355-356). The hair may consist of poisonous caterpillars (Blaffer 1972, 105; Hunt 1977, 105-106). Sisimite are connected particularly with the wild and inhabit forests, ravines, and mountaintops, areas away from settlements. They lack many of the features of human culture, eating raw meat because their long hair is highly flammable and they are afraid to use fire (Thompson 1930, 67). Sisimite also exhibit other bizarre behaviors and often act in ways that transgress social norms. For example, they get up when most people go to bed, and they doze when others interact. They also enter buildings by leaping over walls instead of passing through doors, acquire sexual partners by kidnapping unwary humans rather than through any kind of interaction or courtship, and may even eat human flesh (Hunt 1977, 105-106; Laughlin 1977, 391-392; Costenla 1995; López 2002, Vol. 2, 161, 183). Through these transgressive actions, the sisimite also reinforce gender and sexual norms.

Sisimite are dangerous: death, kidnapping, and insanity are likely fates for the unfortunate individuals who encounter them. Some - like the Honduran sipesipe, which can be a good omen for planting in some situations - may exhibit benevolent behavior, and even sisimite who do inflict harm do not do so randomly. The people who need to fear sisimite are those who have violated local mores. Sisimite are very rarely encountered in daylight hours; drunks and transgressors of sexual norms, who are out when orderly people are at home, are the ones most likely to meet them. Sisimite attacks are also provoked by failure to conform to expected familial behaviors, especially as they relate to gender roles. Though normally avoiding areas of human habitation, sisimite may enter communities to steal the babies of women who have left them unsupervised (López 2002, Vol. 2, 184) or to kidnap inattentive cooks, who have fallen asleep by the fire or left food on the fire unattended.

In some ways, sisimite and cognate beings seem to be inversions of ancient tzitzimime. They are most often male, but sometimes female or apparently female. They inhabit remote earthly places rather than celestial realms and they are "wild," associated with contexts outside the domain of culture. They are clothed in magical hair, not magical textiles; they are also unkempt, unlike their pre-Columbian tztitzimime predecessors who tended to be wellgroomed. Tzitzimime also contributed to social stability by tempering conflict. Devouring people on occasions of universal destruction can be seen as punishment for societal failures to fulfill the obligation to nourish the sun. Tzitzimime also had connections to norms of sexual behavior, though not in obvious roles as enforcers. Sisimite similarly maintain social mores 
in contemporary times, especially in relation to gender roles, drunkenness, and sexual transgression. They enforce norms by removing transgressors from society by killing them, driving them insane, or kidnapping them and forcing them to live in caves. This connection between sisimite and caves is not surprising since their tzitzimime predecessors were sometimes explicitly connected with caves and are associated more generally in Mesoamerican thought with ancestors - often linked to caves and cave-like spaces in Mesoamerican imagery and iconography - and renewal (Henderson and Hudson 2016; Pohl 1998).

The literature on sisimite often emphasizes questions concerning their historical connection with ancient tzitzimime and focused on the relationship of the two labels. However, the use of a term derived from the Nahuatl tzitzimime and the existence of a historical relationship between ethnographic monsters and pre-Columbian tzitzimime are separate issues. In Zinacantan and San Pedro Chenalhó, Chiapas, h7ik'al share the basic characteristics of sisimite, especially in relation to punishing transgressions of conventional gender roles and sexual norms. They are also conceptualized as adversaries of the sun (and the moon), bent on destroying human beings - the key roles of pre-Columbian tzitzimime (Blaffer 1972). Conversely, the sisimite label may sometimes reflect the use of the term by Nahua-speaking allies of Spanish invaders to refer to beings and practices that had several fortuitously similar central Mexican counterparts.

\section{Discussion}

In pre-Columbian conceptualizations, tzitzimime were not monsters in the ordinary sense. They could be malevolent, but they were not fundamentally cruel or destructive. Like all Mesoamerican supernatural beings, tzitzimime were more like sets of supernatural forces that were salient on particular occasions than the discrete, personified deities of Mediterranean pantheons. Those constellations of supernatural features and forces that were often salient fortuitously resembled Spanish notions of deity. This perspective helps to make sense of the bewildering array of names, epithets, and characteristics attributed to tzitzimime. They are at once male and female, benevolent and dangerous, creative and destructive; they cause disease, but they also cure it. These contrasting qualities and their inherent duality fit with the fundamental role of tzitzimime in balancing powerful forces of contrasting character. As supernatural beings, tzitzimime could have unusual anatomical features, but they were not the hybrid monsters of the ancient Near East (Wengrow 2014), combining features of different species. Nor was their behavior exceedingly wicked or otherwise monstrous. 
Following the Spanish invasion, tzitzimime were demonized, becoming progressively more monstrous in the Colonial imagination. Churchmen identified tzitzimime with the devil and his agents; they were simultaneously masculinized, and their more positive attributes were reassigned to saints of other church-sanctioned purveyors of good. Their ethnographic descendants and counterparts represent a continuation of this trajectory. They are anatomically monstrous, especially in terms of bodily proportions. Behaviorally, they are highly dangerous and often cause harm - not because of an evil character, but in their capacity as enforcers of social norms.

We are not yet in a position fully to resolve the historical issue of the relationships of preColumbian tzitzimime and ethnographic sisimite, but they undoubtedly have similar characters and comparable behaviors. They embody and balance dangerous forces, foster social stability and harmony, and punish the transgression of social mores. They fill these roles in quite different socio-political contexts. Ancient tzitzimime functioned within a "political cosmology," in relation to state-sanctioned views of the supernatural. Modern sisimite are part of a world in which those political contexts have been eliminated. The much closer involvement of sisimite with maintenance of norms may be a reflection of the transformed political contexts in which they operate.

\section{References Cited}

Alvarado Tezozómoc, Fernando. 1975. Crónica mexicáyotl. Translated by Adrián León. Mexico: Universidad Nacional Autónoma de México.

Aplicano Mendieta, Pedro. 1967. Leyendas y tradiciones indígenas. Tegucigalpa: Librería Atenea.

Arvey, Margaret C. 1988. "Women of III-repute in the Florentine Codex." In The Role of Gender in Precolumbian Art and Architecture, edited by Virginia E. Miller, 179-204. Lanham: University Press of America.

Berdan, Frances F. 2014. Aztec Archaeology and Ethnohistory. New York: Cambridge University Press.

Blaffer, Sarah C. 1972. The Black-man of Zinacantan: A Central American Legend. Austin: University of Texas Press.

Boone, Elizabeth H. 1999. "The 'Coatlicues' at the Templo Mayor." Ancient Mesoamerica 10 (2): 189-206. 
Carías, Claudia Marcela, Héctor Miguel Leyva, Róger Martínez Miralda, Enma Leticia Ordóñez S., and Jorge F. Travieso. 1988. Tradición oral indígena de Yamaranguila. Tegucigalpa: Editorial Guaymuras.

Chapman, Anne M. 1982. Los hijos de la muerte: el universo mítico de los tolupánjicaques (Honduras). Mexico: Instituto Nacional de Antropología e Historia.

Chapman, Anne M. 1985. Los hijos del copal y la candela: ritos agrarios y tradición oral de los lencas de Honduras. Mexico: Centre d'Études Mexicaines et Centraméricaines and Universidad Nacional Autónoma de México.

Conzemius, Edward. 1932. Ethnographical Survey of the Miskito and Sumu Indians of Honduras and Nicaragua. Bureau of American Ethnology, Bulletin 106. Washington: Smithsonian Institution.

Correa, Gustavo. 1955. "El espíritu del mal en Guatemala: ensayo de semántica cultural." In Nativism and Syncretism, edited by Margaret A. L. Harrison and Robert Wauchope, 37-103. Middle American Research Institute, Publication 19. New Orleans: Tulane University.

Costenla Umaña, Adolfo. 1995. "Sisimique: orígenes indígenas de un personaje del cuento popular costarricense." Filología y Lingüística 21 (2): 16l-168.

Dixon, Boyd. 2008. "Los orígenes del Sipesipe en las leyendas hondureñas." Yaxkin 24 (2): 148-163.

Dodds, Georges T. 2008. "Monkey-Spouse Sees Children Murdered, Escapes to Freedom! A Worldwide Gathering and Comparative Analysis of Camarena-Chevalier Type 714, II-IV Tales. Part II: Beyond Europe." Estudos de Literatura Oral 13-14: 92-97.

Durán, Diego. 1994. The History of the Indies of New Spain. Translated by Doris Heyden. Norman: University of Oklahoma Press.

Escobar Barba, Edgar. 2000. Entre sustos con los ahuizotes. Managua: Ediciones 400 Elefantes.

Espino, Miguel A. 1955. Mitología de Cuscatlán. San Salvador: Ministerio de Cultura.

Hartman, Carl V. 1907. "Mythology of the Aztecs of Salvador." Journal of American Folklore 20 (77): 143-147.

Henderson, John S., and Kathryn M. Hudson. 2016. "Places of Beginning, Modes of Belonging: Steambaths and Caves in Mesoamerica." Contributions in New World Archaeology 10: 149-182.

Hunt, Eva. 1977. The Transformation of the Hummingbird: Cultural Roots of a Zinacantecan Mythical Poem. Ithaca: Cornell University Press. 
Johansson Keraudren, Patrick. 1998. "Tlahtoani y Cihuacoatl: lo diestro solar y lo siniestro lunar en el alto mando Mexica." Estudios de Cultura Náhuatl 28: 39-75.

Klein Cecelia F. 1988. "Rethinking Cihuacoatl: Aztec Political Imagery of the Conquered Woman." In Smoke and Mist: Mesoamerican Studies in Memory of Thelma D. Sullivan, edited by J. Kathryn Josserand and Karen Dakin. 237-277. British Archaeological Reports International Series 402 (1). Oxford: BAR Publishing.

Klein Cecelia F. 2000. "The Devil and the Skirt." Ancient Mesoamerica 11 (1): 1-26.

Klein, Cecelia F. 2008. "A New Interpretation of the Aztec Statue Called Coatlicue, "Snakes-Her-Skirt." Ethnohistory 55 (2): 229-250.

Laughlin, Robert M. 1977. Of Cabbages and Kings: Tales from Zinacantan. Smithsonian Contributions to Anthropology, Number 23. Washington: Smithsonian Institution.

López García, Julián. 2002. Restricciones culturales en la alimentación de Mayas Chortis y Ladinos del Oriente de Guatemala. 2 Vols. Ph.D. dissertation, Madrid: Departamento de Historia Contemporánea, Universidad Complutense de Madrid.

Martínez, Roberto and Katarzyna Mikulska. 2016. "La vida en el espejo: los mundos míticos y sus reflejos entre los nahuas del siglo xvi y otros pueblos de tradición mesoamericana." Dimensión Antropológica 68: 7-52.

Matos Moctezuma, Eduardo. 1987. "Symbolism of the Templo Mayor." In The Aztec Templo Mayor, edited by Elizabeth H. Boone, 185-209. Washington: Dumbarton Oaks.

Matos Moctezuma, Eduardo. 1988. The Great Temple of the Aztecs: Treasures of Tenochtitlan. London: Thames \& Hudson.

Nicholson, Henry B. 1971. "Religion in pre-Hispanic Central Mexico." Handbook of Middle American Indians 10: 395-446.

Olivera de Vázquez, Mercedes. 1969. "Los dueños del agua en Tlaxcalancingo." Boletín del Instituto Nacional de Antropología e Historia 35: 45-48.

Pohl, John M. D. 1998. "Themes of Drunkenness, Violence, and Factionalism in Tlaxcalan Altar Paintings." RES: Anthropology and Aesthetics 33: 184-207.

Quesada Pacheco, Miguel Ángel. 2014. "La leyenda del sisimite en lengua pech. Estudios de Lingüística Chibcha 33: 317-350.

Sahagún, Bernardino de. 1950-1982. Florentine Codex: General History of the Things of New Spain. Edited and translated by Charles E. Dibble and Arthur J. O. Anderson. Salt Lake City: School of American Research and University of Utah Press.

Schroeder, Susan. 2016. Tlacaelel Remembered: Mastermind of the Aztec Empire. Norman: University of Oklahoma Press. 
Sigal, Pete. 2011. "Imagining Cihuacoatl: Masculine Rituals, Nahua Goddesses and the Texts of the Tlacuilos." In Historicising Gender and Sexuality, edited by Kevin P. Murphy and Jennifer M. Spear, 12-37. London: Blackwell Publishing.

Thompson, J. Eric S. 1930. Ethnology of the Mayas of Southern and Central British Honduras. Anthropological Series 17 (2). Chicago: Field Museum of Natural History.

Wengrow, David. 2014. The Origins of Monsters: Image and Cognition in the First Age of Mechanical Reproduction. Princeton: Princeton University Press.

Wisdom, Charles. 1940. The Chorti Indians of Guatemala. Chicago: University of Chicago Press.

Kathryn Hudson is a Research Assistant Professor in the Department of Anthropology at the University at Buffalo and also a member of the Department of Linguistics. Her research focuses primarily on mechanisms of identity construction, processes of visual and non-verbal communication, ceramic analysis, and the documentation of cultural and linguistic traditions. Her main geographic foci are Mexico and Central America, southeastern Europe, the Pacific, and the southeastern United States.

John S. Henderson is Professor of Anthropology and Archaeology at Cornell University. He holds MPhil and PhD degrees in Anthropology from Yale University. His interests center on early complex societies, especially how distinctions in status, wealth, and authority developed and how imagery and text have been deployed to maintain and enhance them. Another set of interests revolves around identity: how the groups with which people associate themselves are reflected in archaeological remains. He has explored these issues through material remains, imagery, and written texts in Mexico and Central America, especially in Honduras

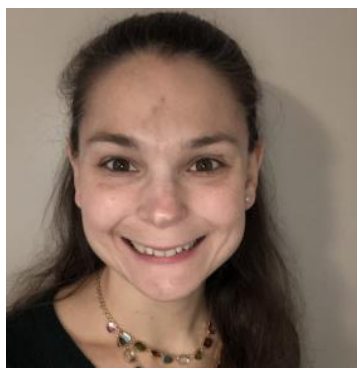
where he has directed many seasons of field research. His books and monographs include Lowland Maya Civilization in the Eighth Century A.D. (1993, co-edited with Jeremy A. Sabloff); Configurations of Power: Holistic Anthropology in Theory and Practice (1993, co-edited with Patricia J. Netherly); Pottery of Prehistoric Honduras: Regional Classification and Analysis (1993, co-edited with Marilyn P. Beaudry-Corbett); Archaeology in Northwestern Honduras: Interim Reports of the Proyecto Arqueologico Sula (1984); Atopula, Guerrero, and Olmec Horizons in Mesoamerica (1979). 